Niniejsza publikacja jest dostęna na licencji Creative Commons. Uznanie autorstwa-Użycie niekomercyjne-Bez utworów zależnych 3.0 Polska. Pewne prawa zastrzeżone na rzecz autora. Zezwala się na wykorzystanie publikacji zgodnie z licencja - pod warunkiem zachowania niniejszej informacji licencyjnej oraz wskazania autora jako właściciela praw do tekstu. Treść licencji jest dostępna na stronie: http://creativecommons.org/licenses/by-nc-nd/3.0/pl/

Lingwistyka Stosowana 23: 3/2017, 213-227

\author{
Mieczysław NASIADKA \\ Uniwersytet Warszawski
}

\title{
Typy translatorów automatycznych w tłumaczeniu metafor
}

\begin{abstract}
:
Different Types of Machine Translation Systems in the Process of Translating Metaphors

The two main topics discussed in this article are machine translation systems and metaphorical constructions translated by such systems. I briefly present the history of machine translation, its evolution and types of the most widespread engines, taking into account their architecture. I describe rule-based, statistical and neural machine translation, taking Translatica PWN, Google Statistical and Google Neural Machine Translation systems respectively as examples. Having discussed the notion of metaphor, I finally analyse examples of metaphorical expressions and idioms translated by the described engines, compare the final outcome and present my conclusions.
\end{abstract}

\section{Wstęp}

W dobie globalizacji i ogromnej ilości ciągle nowych informacji (już w 2011 r. firma EMC Corporation, zajmująca się produkcją systemów zarządzania i przechowywania danych, podała, że zasób informacji tworzonych na świecie, mierzony w bilionach gigabajtów, wzrasta przeszło dwukrotnie co dwa lata - zob. J. Gantz/ D. Reinsel 2011) wielkim problemem staje się dostęp do tych informacji. Stajemy przed koniecznością tłumaczenia niezliczonej ilości tekstów i wypowiedzi. Niestety tłumacze-ludzie coraz częściej nie są w stanie poradzić sobie z tym zadaniem i dlatego musi rosnąć rola oprogramowania tłumaczącego, które nie tylko ma pomagać człowiekowi, ale coraz częściej ma go zastępować w procesie tłumaczenia.

Aby jakość tłumaczenia wykonywanego przez systemy komputerowe była akceptowalna, muszą one ,umieć”, podobnie jak człowiek, radzić sobie z wieloma problemami translatorskimi. Dlatego ciągle trwają prace nad udoskonalaniem istniejących systemów tłumaczących ${ }^{1}$ i nad rozwojem zupełnie nowych rozwiązań.

Jednym z problemów, szczególnie trudnym do przezwyciężenia dla oprogramowania tłumaczącego, jest brak tzw. dosłowności tekstu wejściowego, czyli jego wieloznaczność, która często jest wynikiem obecności metafory i konstrukcji idiomatycznych. W niniejszym artykule dokonuję przeglądu wybranego oprogramowania tłumaczącego pod kątem jego zdolności do tłumaczenia metafor i idiomów.

\footnotetext{
${ }^{1}$ http://www.statmt.org/moses/?n=Moses.Background.
} 


\section{Tłumaczenie automatyczne - historia}

Mówiąc tu o thumaczeniu automatycznym mam na myśli wykorzystanie oprogramowania thumaczącego przede wszystkim do tłumaczenia tekstów pisanych (zob. K. Ping 2011: 162 i nast., M. Gajer 2008: 15). Oprogramowanie takie można najprościej podzielić na trzy podtypy: wspomagające pracę tłumacza (MAHT, Machine Aided Human Translation, do którego zaliczymy np. pamięci tłumaczeniowe, słowniki elektroniczne, również on-line); programy wymagające niewielkiej pomocy człowieka, który np. dokonuje pre-edycji tekstu poddawanego thumaczeniu (HAMT, Human Aided Machine Translation) oraz thumaczenie całkowicie zautomatyzowane, wykonywane samodzielnie przez silnik thumaczący (FAMT, FAHQMT, odpowiednio Fully Automated Machine Translation i Fully Automated High-Quality Machine Translation, zob. Ł. Bogucki 2009). W niniejszym artykule skupię się na ostatnich trzech typach oprogramowania thumaczącego (HAMT, FAMT, FAHQMT).

Niektórzy entuzjaści tłumaczenia maszynowego skłonni są doszukiwać się jego początków już w XVII w., w poglądach filozoficznych Kartezjusza i Leibniza na temat języków uniwersalnych i logicznych, czy w pracach J. Bechera oraz J. Wilkinsa nad stworzeniem języka uniwersalnego (interlingwy; zob. J. Hutchins 2004: 1). Pewną automatyzację thumaczenia, niestety nadal w bardzo ograniczonym zakresie, osiągnięto jednak dopiero w XX w., wraz z budową prostych mechanicznych maszyn thumaczących. Przykłady warte odnotowania to, m.in., urządzenia P. Trojańskiego i G. Artsrouniego, które powstały jeszcze przed II wojną światową, niezależnie, w Rosji i Francji (zob. J. Hutchins 2004, Ł. Bogucki 2009: 38 i nast.) oraz „wspólny projekt Uniwersytetu Georgetown i firmy IBM”, przedstawiony w $1954 \mathrm{r}$. (zob. Ł. Bogucki 2009: 40). Pomimo bardzo intensywnych prac, systemy thumaczące z początku drugiej połowy XX w. i późniejsze nieźle się sprawdzały tylko w tłumaczeniu wąsko sprofilowanych tekstów, np. wojskowych, a nadzieje w tym zakresie były znacznie większe. Można tu wymienić takie oprogramowanie jak SYSTRAN, Susy, Météo czy Atlas (zob. Ł. Bogucki 2009: 42 i nast.). Od początku pragnęliśmy tworzyć systemy uniwersalne, radzące sobie z tłumaczeniem tekstów $\mathrm{z}$ różnych dziedzin, a nawet z tekstami literackimi, jednak zwłaszcza tu jakość tłumaczenia kolejnych systemów tłumaczących była zła.

\section{Typy oprogramowania tlumaczącego}

Oprogramowanie tłumaczące można dzielić na różne typy w zależności od bazy albo tzw. metody, na której się opiera i, w związku z tym, istnieje tu wiele klasyfikacji. Dokładniej omówię trzy typy, ale dla uzyskania pełniejszego obrazu zagadnienia wspominam również inne stosowane rozwiązania. Poniżej przedstawiam nieco zmienioną i uzupełnioną przeze mnie klasyfikację C.K. Quah (2006, przytaczam za Ł. Bogucki 2009: 35, zob. też D. Arnold 2003: 122 i nast., K. Ping 2011: 162 i nast., M. Nasiadka 2016). Jest to podział uwzględniający kolejne generacje oprogramowania thumaczącego automatycznie: 
1) thumaczenie bezpośrednie (z 1 języka naturalnego na 2 język naturalny; początkowo słowo za słowo i ogólne reguły gramatyczne, morfologiczne i składniowe);

2) thumaczenie oparte na regułach, pośrednie (RBMT - Rule-Based Machine Translation, zyskało popularność pod koniec XX w.):

a) interlingwa (thumaczenie na międzyjęzyk, którym może być również język naturalny, np. j. angielski; jeden system można zastosować dla więcej niż 2 języków);

b) transfer (analiza, transfer przetłumaczonych elementów, synteza; zestaw reguł transferowych, np. gramatycznych, dla konkretnej pary języków, thumaczenie w drugą stronę wymaga nowego kompletu reguł);

3) thumaczenie korpusowe, czasem też zbiorczo nazywane „opartym na przykładach" (CBMT - Corpus-Based Machine Translation, EBMT Example-Based Machine Translation - przez analogię, wykorzystuje autentyczne teksty i zdania):

a) statystyczne (STM - Statistical Machine Translation, zdanie dzielone na wyrazy lub na frazy, a następnie thumaczenie i wybór najbardziej prawdopodobnej formy przy użyciu rachunku prawdopodobieństwa);

b) oparte na przykładach (korpusowe, ale przez analogię);

4) systemy mieszane (multi-engine MT systems - rozwiązania z pkt. 2 i 3 ).

Dzisiaj z pewnością trzeba do tej listy dopisać kolejną pozycję:

5) thumaczenie oparte na sieciach neuronowych (NMT - Neural Machine Translation).

Ponieważ w dalszej części artykułu dokonuję analizy przykładów tłumaczenia konstrukcji metaforycznych przez trzy wybrane silniki tłumaczeniowe, omówię tu nieco dokładniej zasady ich działania.

\subsection{Translatory oparte na regulach (RBMT, systemy pośrednie)}

Translatory tego typu wykorzystują rozbudowane reguły danego języka (gramatyczne, składniowe, morfologiczne) do analizy tłumaczonego zdania i dokonują tzw. parsingu, czyli jego rozbioru, w rezultacie którego każdemu słowu przypisana zostaje określona funkcja (np. podmiotu, orzeczenia, dopełnienia) oraz relacje składniowe (drzewa). Następnie system wykonuje tzw. transfer językowy, czyli tłumaczy analizowane zdanie na „surowe" zdanie w języku docelowym. Na kolejnym etapie dodaje do niego elementy gramatyki, składni i morfologii języka docelowego. Ważnym elementem takich rozwiązań są rozbudowane słowniki dwujęzyczne, zawierające również formy pochodne słów i reguły ich użycia (zob. Ł. Bogucki 2009: 33).

Opisywane translatory wyróżniają się względnie dobrą jakością thumaczenia, ale opracowanie translatora spełniającego swoje zadanie zajmuje nawet kilka lat $\mathrm{i}$, niestety, nie „nadążają” one za bogactwem leksyki, dlatego ich (dwujęzyczne) słowniki muszą być ciągle uzupełniane o neologizmy i niestandardowe odmiany. Inną wadą silników opartych na regułach (i transferze) jest brak uniwersalności - thumaczą tylko pomiędzy ustalonymi parami języków i słabo radzą sobie z możliwymi odstępstwami od reguł językowych (niestandardową składnią; zob. Ł. Bogucki 2009: 33). 
Znanym u nas przykładem takiego systemu jest program thumaczący Translatica PWN. Działa on w oparciu o rozbudowane reguły gramatyczne i składniowe oraz dwujęzyczne słowniki, ale również - według PWN - o korpusy tekstowe. Jest to więc translator mieszany, oparty na regułach, ale z dodanymi innymi rozwiązaniami. W oparciu o reguły Translatica przeprowadza parsing, czyli dokonuje analizy składniowej i semantycznej oryginalnego tekstu, a następnie dobiera ekwiwalenty w języku, na który thumaczy. Pomimo widocznych błędów tłumaczeniowych, na przykładzie Translatiki widać, że - nie tylko jak na system automatyczny (zob. M. Nasiadka 2016) - jakość tłumaczenia jest względnie dobra.

\subsection{Translatory korpusowe (CBMT, EBMT, SMT)}

Systemy korpusowe, w ramach których możemy wyróżnić statystyczne i oparte na przykładach (wg klasyfikacji powyżej), nie wykorzystują rozbudowanych reguł gramatycznych i syntaktycznych (języka naturalnego), a ich opracowanie wymaga mniej czasu i mniejszego nakładu pracy niż opracowanie systemów RBMT. Są od nich również bardziej uniwersalne, ponieważ nie potrzebują słowników przygotowanych dla konkretnej pary języków (przywoływana powyżej Translatica PWN thumaczy tylko pomiędzy 4 językami). Potrzebują za to dużych korpusów równoległych dla danych par języków, zawierających nawet kilka milionów jednostek.

Ogromne korpusy tekstów (przykładów) to jeden z filarów tłumaczenia statystycznego. Kolejne to (matematyczna) teoria informacji i rachunek prawdopodobieństwa ${ }^{2}$. Za twórcę matematycznej teorii informacji uważa się Claude'a E. Shannona, autora m.in. „A Mathematical Theory of Cryptography” $(1945)^{3}$ i „A Mathematical Theory of Communication” (1948) oraz współautora „The Mathematical Theory of Communication” (1949). Teoria ta „charakteryzuje w sposób matematyczny zapis, przesyłanie i odtwarzanie informacji. Dąży przy tym do pogodzenia dwóch przeciwstawnych celów:

1. zapisywania wiadomości jak najzwięźlej,

2. chronienia wiadomości przed przekłamaniami podczas transmisji" (I. Bondecka-Krzykowska) ${ }^{4}$.

Prace nad rozwojem translatorów opartych na metodzie statystycznej rozpoczęła już w drugiej połowie lat 80 . ubiegłego wieku firma $\mathrm{IBM}^{5}$, a systemy tłumaczenia statystycznego drugiej generacji umiały już rozpoznawać relacje pomiędzy całymi frazami, a nie tylko pomiędzy wyrazami (jak pierwsze), w wyniku czego pojedynczym wyrazom z korpusów równoległych można było przypisać, w razie konieczno-

\footnotetext{
${ }^{2}$ Zob. Ł. Bogucki (2009: 34): „Kluczowym pojęciem jest tu [jak największe] prawdopodobieństwo, że dany ciąg wyrażeń jest tłumaczeniem ciągu wyrażeń w języku źródłowym”.

3 Opublikowana została dopiero krótsza - odtajniona - wersja tej pracy pod tytułem „Communication Theory of Secrecy Systems"; nastąpiło to w 1949 r. https://www.iacr.org/museum/shannon/shannon45.pdf.

${ }^{4}$ http://www.graniczne.amu.edu.pl/PPGWiki/attach/InformacjaW1Prezentacja/teoria\%20ko munikacji\%20Shannona.pdf f; dostęp 29.03.2017 r.

${ }^{5} \mathrm{http}: / /$ www.statmt.org/moses/?n=Moses.Background.
} 
ści, więcej niż jeden wyraz/frazę (zob. P.F. Brown/ V.J. Della Pietra i in. 1993, zob. F.J. Och 2003, zob. I. Tsikarishvili 2015).

Translatory statystyczne trzeba uczyć modelu języka, czyli tego, jak w danym języku thumaczenia wyglądają poprawne zdania, by na tej podstawie, przy wykorzystaniu rachunku prawdopodobieństwa, system mógł zbudować jak najbardziej poprawne thumaczenie (trzeba je trenować w obu kierunkach; zob. K. Marasek/ K. Wołk i in. 2014, zob. I. Tsikarishvili 2015). Warto zaznaczyć, że translator wykorzystujący metodę statystyczną możemy stworzyć sobie sami, wykorzystując np. dostępny on-line system Moses, który jest na bieżąco aktualizowany ${ }^{6}$.

\subsection{Translatory oparte na sieciach neuronowych (NMT)}

Prace zmierzające do stworzenia sieci sztucznych neuronów (czyli elektronicznych systemów zbudowanych na wzór sieci neuronów biologicznych), służących do przetwarzania różnych wartości sygnałów wejściowych w jedną wartość wyjściową i posiadających zdolność uczenia się, rozpoczęły się już kilkadziesiąt lat temu. Można przyjąć, że graniczną datą był tu rok 1943, w którym neurobiolog Warren S. McCulloch i logik Walter Pitts opisali schemat działania takiego neuronu, wzorowany na pracy neuronu naszego mózgu ${ }^{7}$. Pierwsze proste urządzenie - perceptron zbudowane ze sztucznych neuronów stworzył Frank Rosenblatt już w 1957 roku.

Podobnie jak w przypadku prac nad dwoma omówionymi powyżej systemami thumaczącymi, opartym na regułach i statystycznym, prace nad sieciami neuronowymi po pierwszych niepowodzeniach zarzucono na kilka dziesięcioleci, by ponownie zacząć poważnie myśleć o ich efektywnym wykorzystaniu dopiero w latach 90. ubiegłego wieku (zob. też. S. Hochreiter/ J. Schmidhuber 1997); prace nad przywoływanym tu przeze mnie translatorem opartym na głębokich sieciach neuronowych - Google's Neural Machine Translation - rozpoczęły się dopiero w 2011 r. tajnym projektem o nazwie „Google Brain” (zob. Q.V. Le/ M. Schuster 2016).

Systemy thumaczące oparte na sztucznych sieciach neuronowych to najnowsze osiągnięcie lingwistyki komputerowej, uważne za bardzo obiecujące, choć, jak zobaczymy za chwilę, wymagające ulepszeń. $Z$,ttumaczeniem neuronowym” wiąże się tak duże nadzieje na poprawę jakości thumaczenia automatycznego, że jesienią 2016 r. firma Google ogłosiła, że będzie zastępowała statystyczny silnik swojego internetowego serwisu Google Translate systemem Google Neural Machine Translation (GNMT). Niestety obecnie jest on wykorzystywany tylko dla kilkunastu języków (od listopada 2016 r. dla angielskiego, francuskiego, niemieckiego, hiszpańskiego, portugalskiego, chińskiego, japońskiego, koreańskiego i tureckiego, a od marca 2017 r. również dla hindi i wietnamskiego - zob. Y. Yushkina 2017).

Dlaczego thumaczenie automatyczne oparte na modelach wykorzystujących sieci neuronowe ma być lepsze w porównaniu do wykonywanego przez translatory oparte na metodzie statystycznej? Otóż SMT, jak zaznaczyłem powyżej, rozbija zdania wejściowe na wyrazy lub frazy, które tłumaczy oddzielnie, a następnie buduje z nich

\footnotetext{
${ }^{6} \mathrm{http}: / /$ www.statmt.org/moses/index.php?n=Main.HomePage.

${ }^{7}$ https://pdfs.semanticscholar.org/5272/8a99829792c3272043842455f3a110e841b1.pdf.
} 
zdania w języku docelowym (w przypadku Google Translate w wersji statystycznej dochodzi jeszcze tłumaczenie na język pośredni, którym, w każdym przypadku, jest język angielski). Takie rozbijanie i ponowne składanie zdań często zakłóca ich sens, zwłaszcza jeśli zdanie wejściowe jest długie i musi być rozbite na większą liczbę fraz. Translatory działające w oparciu o sieci neuronowe są uczone sensu i thumaczenia całych zdań (bez rozbijania ich na frazy), co ma poprawiać jakość tłumaczenia i - co najważniejsze - mają zdolność ciągłego (samodzielnego) uczenia się. Samo Google ocenia, że jakość jego thumaczenia typu NMT jest lepsza w stosunku do SMT o około 60\% (zob. też Y. Wu/ M. Schuster/ Z. Chen i in. 2016), a jeden z pierwszych profesjonalnych systemów thumaczenia maszynowego, wspomniany wyżej SYSTRAN, który zaczynał jako RBMT, a w 2010 r. zmienił się w system hybrydowy RBMT/SMT, dzisiaj jest systemem NMT, jak przeczytamy na stronie firmowej. ${ }^{8}$

Główne wady systemów NMT, z którymi od początku musieli mierzyć się programiści, to znowu konieczność ich uczenia - odpowiednio długiego dla dobrych efektów - oraz fakt, że słabo one sobie radzą z tłumaczeniem mniej pospolitych słów. Opracowano już jednak metody radzenia sobie z tymi wadami (zob. Y. Wu/ M. Schuster/ Z. Chen i in. 2016), przynajmniej częściowo.

\section{Metafora - jak ją rozumieć}

Zanim przystąpię do analizy wyników thumaczenia konstrukcji metaforycznych przez wybrane translatory automatyczne, wyjaśnię, jak rozumiem pojęcie „metafora" i jakiego typu konstrukcje poddam thumaczeniu.

Okazuje się, że sformułowanie definicji metafory zadowalającej wszystkich jest zadaniem niezwykle trudnym, może nawet niemożliwym do wykonania, nawet po długich studiach nad metaforą ${ }^{9}$, i zapewne każdy z nas podałby inny opis tego pojęcia. Zauważa to np. T. Krzeszowski (2006: 37): „o metaforze już od dawna wygłasza się sprzeczne ze sobą poglądy. Na przykład na temat tego, czy metafora jest jedynie figurą stylistyczną i ozdobnikiem językowym, czy też, przeciwnie, sięgającym w głąb ludzkiego umysłu narzędziem poznania". Nie mając pewności co do tego, czym jest metafora, sięgnijmy do słownika. I tak internetowy "Słownik języka polskiego PWN”"10 informuje, że „metafora” to inaczej „przenośnia” czyli

(...) figura stylistyczna występująca zwykle w poezji, oparta na skojarzeniu dwóch zjawisk i przeniesieniu nazwy jednego zjawiska na drugie, np. 'stalowe nerwy'.

W „Popularnym słowniku języka polskiego” pod red. B. Dunaja (2001) pod hasłem „metafora” przeczytamy:

\footnotetext{
${ }^{8} \mathrm{http}: / / \mathrm{www}$. systransoft.com/systran/translation-technology/pure-neural-machinetranslation/.

9 „Trzeba pewnej odwagi, a nawet lekkomyślności, by bez długich studiów przygotowawczych wypowiadać się dzisiaj o metaforze" (H. Markiewicz 1984: 43, cyt. za T. Krzeszowski 2006:37).

${ }^{10} \mathrm{https}$ ://sjp.pwn.pl/sjp/przenosnia;2510775.html. Oryginalnie pod red. W. Doroszewskiego.
} 
(...) figura stylistyczna, której istotą jest łączenie słów w taki sposób, że co najmniej jedno z nich uzyskuje nowe, przenośne znaczenie, pozostające (nieraz w bardzo odległym) związku ze znaczeniem podstawowym; przenośnia.

O dziwo, ten sam słownik podobnie definiuje ,idiom”:

(...) wyrażenie lub zwrot językowy, którego nie można rozumieć dosłownie ani dosłownie przetłumaczyć na inny język, np. biały kruk, rzucić okiem.

Metafora jest definiowana bardzo podobnie również w obcojęzycznych pozycjach leksykograficznych, np. w angielskojęzycznym ,The New Shorter Oxford English Dictionary" (L. Brown 1993):

1. A figure of speech in which a name or descriptive word or phrase is transferred to an object or action different from, but analogous to, that to which it is literally applicable; an instance of this, a metaphorical expression. 2. A thing considered as representative of some other (usu. abstract) thing; a symbol. It is a metaphor if you describe Oxford as a hive of industry.

Inne pojmowanie metafory - jako narzędzia poznania (metafora pojęciowa, konceptualna) - rozpropagowały prace amerykańskich kognitywistów G. Lakoffa i M. Johnsona (1980 i 1999) oraz G. Lakoffa i M. Turnera (1989), do których do dzisiaj odwołują się setki kolejnych badaczy (zob. też Z. Kövecses 2002). Publikacje te totalnie zmieniły nasze spojrzenie na metaforę, czyniąc ją, cytując Lakoffa i Johnsona (1980: ix), ,a matter of central concern, perhaps the key to giving an adequate account of understanding" [sprawą najwyższej wagi, najprawdopodobniej zjawiskiem kluczowym dla naszego poznania - tłum. M. N.], czymś, co nadaje ramy naszej percepcji świata, naszemu myśleniu i działaniu (zob. G. Lakoff/ M. Johnson 1980:4 i nast.). Przykłady metafory pojęciowej to konstrukcje typu CZAS TO PIENIĄDZ i ŻYCIE TO PODRÓŻ, realizowane na różne sposoby w aktach komunikacji.

Pojmowana w ten sposób metafora to odwzorowanie jednej domeny pojęciowej (źródłowej) na drugą (docelową), dzięki czemu domena docelowa zyskuje strukturę domeny źródłowej, co - ze względu na to, że domena docelowa często jest abstrakcyjna - pozwala nam ją lepiej zrozumieć (bardziej „,dosłownie”). I tak, zgodnie z metaforą ŻYCIE TO PODRÓŻ, naszą egzystencję postrzegamy jako przebywanie drogi, czynność, która ma początek i koniec, różne etapy pośrednie, na których spotykamy innych wędrowców i przeżywamy przygody, do której należy się odpowiednio przygotować. Widać to choćby w takich konstrukcjach jak ,Zamknąłem pewien etap mojego życia”, „Ostatnio trochę się pogubił, ale wyszedł na prostą”, czy angielskich „We're through the worst of the recession”, „We're out of the woods now”.

Które przedstawienie metafory jest właściwsze? Cytując T. Krzeszowskiego (2006: 37), można by odpowiedzieć, że jest to pytanie „nierozwiązywalne, a to z powodu odmiennych założeń filozoficzno-lingwistycznych, jakie fundują te pozornie sprzeczne ze sobą sądy (...)". Wydaje się jednak, że opisane tu stanowiska wcale się wzajemnie nie wykluczają, a raczej uzupełniają: Lakoff, Johnson i inni kognitywiści postrzegają metaforę szerzej, jako rusztowanie dla naszego fizycznego (cielesnego) doświadczania świata (wyróżniając przy okazji metafory strukturalne, 
orientacyjne i ontologiczne), a definicje słownikowe są raczej opisami konkretnych realizacji metafor pojęciowych.

Warto tu też zauważyć, że często mamy również problem z odróżnieniem metafory od idiomu, także dlatego, że w definicjach tych pojęć można dostrzec elementy wspólne. Upraszczając sprawę, dla potrzeb niniejszego artykułu i przeprowadzanego testu tłumaczenia maszynowego, wykorzystałem różnego typu konstrukcje niedosłowne, spełniające kryteria definicji i metafory, i idiomu np. według B. Dunaja, które często da się szybko zidentyfikować jako realizacje konkretnych metafor pojęciowych w kognitywnej koncepcji metafory. Wszystkie te konstrukcje niewątpliwie biorą swój początek w ludzkim doświadczeniu i obserwacji świata.

\section{Metafora $w$ thumaczeniu automatycznym - wybrane translatory i przykłady tlumaczenia}

Jak powszechnie wiadomo, metafory, idiomy i wszelkiego rodzaju niedosłowne interpretacje tekstu są prawdziwym wyzwaniem dla thumaczy (zob. A. Pisarska 1989, A. Pisarska/ T. Tomaszkiewicz 1998, K. Hejwowski 2009: 38 i nast., M. Nasiadka 2016). Jest tak nie tylko dlatego, że często niosą one inne znaczenia, niż tzw. podstawowe znaczenia tworzących je słów, ale też dlatego, że są nacechowane kulturowo, czyli silnie powiązane z ludźmi, obszarem i językiem, w których powstały.

$\mathrm{Z}$ tych samych powodów problemy $\mathrm{z}$ thumaczeniem konstrukcji niedosłownych mają również translatory automatyczne. Okazuje się też, że i ludzie, i programy thumaczące (te ostatnie dlatego, że tak je napisano) stosują podobne rozwiązania, strategie i techniki thumaczeniowe, takie jak zachowanie metafory, jej modyfikację (np. poprzez wykorzystanie innych domen źródłowej i docelowej) czy, w ostateczności, jej eliminację i zastąpienie tłumaczeniem dosłownym (zob. K. Hejwowski 2009: 71 i nast.).

Poniżej prezentuję wybrane przykłady thumaczenia konstrukcji metaforycznych/ niedosłownych przez wybrane silniki thumaczące: T-RBMT (Translatica), G-NMT (Google) i G-SMT.

I. Metafory pojęciowe - postać ogólna i przykłady ${ }^{11}$

1. ARGUMENT IS WAR (wersja wyjściowa: angielska)

1.1. His criticisms were right on target.

1.2. If you use that strategy, he'll wipe you out.

1.3. He shot down all of my arguments.

T-RBMT

1. ARGUMENT JEST WOJNĄ

1.1. Jego krytyki trafily prosto $\mathrm{w}$ cel.

1.2. Jeśli wykorzystasz tę strategię, on wytrze cię.

1.3. Zastrzelił wszystkich z moich argumentów.

${ }^{11}$ Oryginalne przykłady pochodzą z G. Lakoff/ M. Johnson 1980. Na ich podstawie stworzyłem również polskie wersje wyjściowe. 


\section{G-NMT}

1. ARGUMENT JEST WOJNA

1.1. Jego krytyka miała rację.

1.2. Jeśli użyjesz tej strategii, wytępi cię.

1.3. Zestrzelił wszystkie moje argumenty

1. KŁÓTNIA TO WOJNA (wersja wyjściowa: polska)

1.1. Jego krytyka trafiła prosto w cel.

1.2. Jeśli zrealizujesz tę strategię, on zetrze cię w proch.

1.3. Storpedował wszystkie moje argumenty.

\section{T-RBMT}

1. A QUARREL IS A SIMPLE CARD GAME FOR TWO PEOPLE

1.1. His critics hit the target straight.

1.2. If you fulfil this strategy, he will annihilate you.

1.3. He torpedoed all my arguments.

G-NMT

1. THE BAND IS THE WAR

1.1. His criticism hit the target.

1.2. If you implement this strategy, he will crush you in the dust.

1.3. He torpedoed all my arguments.

2. HEALTH AND LIFE ARE UP; SICKNESS AND DEATH ARE DOWN (wersja wyjściowa: angielska)

2.1. He's at the peak of health.

2.2. He is in top shape.

2.3. He came down with the flu.

T-RBMT

2. ZDROWIE I ŻYCIE NIE ŚPIĄ; CHOROBA I ŚMIERĆ SĄ NA DOLE

2.1. On jest w godzinach szczytu zdrowia.

2.2. On jest w maksymalnym kształcie.

2.3. Dostał grypy.

G-NMT

2. ZDROWIE I ŻYCIE JEST; SZKODLIWOŚĆ I ŚMIERĆ

2.1. Jest w szczytowym stanie zdrowia.

2.2. Jest w najlepszym kształcie.

2.3. Zstąpił z grypą.

2. ZDROWIE TO GÓRA; CHOROBA I ŚMIERĆ TO DÓŁ (wersja wyjściowa: polska)

2.1. Jest w szczytowej formie.

2.2. Jest w najwyższej formie.

2.3. Zmogła go grypa. 


\section{T-RBMN}

2. A HEALTH IS HIGH NOTES; ILLNESS AND THE DEATH ARE LOW NOTES

2.1. He is in the top tin.

2.2. He is in the highest form.

2.3. Influenza overcame him.

\section{G-NMT}

\section{HEALTH IS HIGH; SICK AND DEATH IS DOWN}

2.1. It is in its peak form.

2.2. It is in the highest form.

2.3. It was influenced by the flu.

\section{Idiomy/metafory obrazowe}

1. „Najlepszym może rozwiązaniem jest metoda kija i marchewki: marchewką jest fakt otrzymywania zasiłku, a kijem jego niewielka wysokość i skrócony czas wypłacania, co zmusza do traktowania tej sytuacji jako przejściowej i poszukiwania pracy. $" 12$

\section{T-RBMT}

Best is perhaps ending carrot and stick approach: a fact of receiving a benefit is a carrot, and with bat his little pitch and the shortened time of paying what is forcing to treat this situation as transitional and of job-hunt.

\section{G-NMT}

The best solution is the stick and carrot method: the carrot is the fact of receiving benefits, and the stick is its small height and reduced pay time, which forces you to treat this situation as a transitional and job search.

2. Zaczynają się schody (zaczynają się problemy, sytuacja staje sie trudna) „Wielce pożądaną formą tańca jest kiwanie się tudzież podskakiwanie w towarzystwie mężczyzny - i tu zaczynają się schody, ponieważ zdecydowanie brakuje mężczyzn, którzy potrafią fachowo kiwać się oraz podskakiwać, zwłaszcza w rytm muzyki. "13

T-RBMT: Highly dribbling as well as jumping up in the company of the man are a desired form of the dance - and here stairs are beginning, since the determination is sorting men which are able professionally to dribble and to jump up, especially into the rhythm of the music.

G-NMT: The most desirable form of dancing is jumping or bouncing in the company of a man - and here the stairs begin, because there are definitely no men who can expertly nod and jump, especially in the rhythm of music.

III. Tłumaczenie „dosłownego” tekstu

\footnotetext{
${ }^{12} \mathrm{http} / / /$ sjp.pwn.pl/korpus/zrodlo/metoda-kija-i-marchewki;1072,4;10272.html.

${ }^{13} \mathrm{http}: / /$ sjp.pwn.pl/korpus/zrodlo/kiwanie-sie;241,2;10101.html.
} 
,Wstęp

Ontologie stosowane jako wysoce sformalizowane modele wiedzy stanowią przedmiot zainteresowania przede wszystkim ekspertów w dziedzinie inżynierii informatycznej. Zagadnienie ontologii w systemach informatycznych wzbudziło także dyskusję naukową na gruncie lingwistyki, zwłaszcza lingwistyki języków specjalistycznych oraz terminologii, która jednak do tej pory nie została należycie zainicjowana w polskim środowisku badawczym. Niniejszy artykuł stanowi próbę rozważenia kwestii sposobu reprezentowania wiedzy przez ontologie w świetle antropocentrycznej teorii języków oraz antropocentrycznej teorii języków specjalistycznych.” (A. Bajerowska 2017: 1).

\section{T-RBMT}

Admission

Applied Ontologies as highly formalised models of the knowledge constitute the object of the interest above all of experts in the domain of computer engineering. The issue of ontology in computer systems aroused also scientific discussion on land of linguistics, especially a linguistics of specialist languages and the terminology however which so far properly wasn't initiated in the Polish research environment. The present article constitutes the attempt to consider the matter of the manner of the knowledge representation by ontologies in the light of the anthropocentric theory of languages and of the anthropocentric theory of specialist languages.

\section{G-NMT}

Admission

Ontologies used as highly formalized knowledge models are of primary interest to experts in the field of computer engineering. The problem of ontology in information systems has also aroused scientific discussion on linguistics, especially linguistics of specialized languages and terminology, which, however, has not been properly initiated in the Polish research environment. This article is an attempt to consider the question of how knowledge is represented by ontologies in the light of anthropocentric theory of languages and the anthropocentric theory of specialized languages.

IV. Idiomy - porównanie wyników tłumaczenia przez Google Translate w wersji statystycznej (G-SMT 2015), neuronowej (G-NMT 2017) oraz przez silnik oparty na regułach (Translatica PWN, T-RBMT 2015). ${ }^{14}$

\footnotetext{
${ }^{14}$ Ponieważ translator Google nie jest już dostępny w wersji SMT, dla potrzeb porównania wyników thumaczenia starszego oprogramowania $\mathrm{z}$ wynikami oprogramowania w wersji opartej na sieciach neuronowych przykłady idiomów i ich tłumaczenia przez G-SMT 2015 oraz T-RBMT 2015 zaczęrpnąłem z pracy licencjackiej A. Szczepańczyk pt. „Tłumaczenie maszynowe wybranych typów idiomów przez translatory Translatica i Google Translate analiza porównawcza". Zdania zawierające te idiomy pochodzą ze słowników internetowych: https://www.diki.pl/ oraz http://www.thefreedictionary.com/.
} 


\begin{tabular}{|c|c|c|c|}
\hline & G-SMT 2015 & G-NMT 2017 & T-RBMT 2015 \\
\hline to bite the bullet & zacisnąć zęby & ugryźć kulę & chwycić byka za rogi \\
\hline zdanie & \multicolumn{3}{|c|}{$\begin{array}{l}\text { "You're the one who's going to have to bite the bullet if anything goes } \\
\text { wrong." }\end{array}$} \\
\hline G-NMT & \multicolumn{3}{|c|}{ Jesteś tym, który będzie musiał ugryźć kulę, jeśli coś pójdzie nie tak. } \\
\hline & G-SMT 2015 & G-NMT 2017 & T-RBMT 2015 \\
\hline $\begin{array}{l}\text { to kick the } \\
\text { bucket }\end{array}$ & z kopyta & kopać wiadro & umrzeć \\
\hline zdanie & \multicolumn{3}{|c|}{ "I'm trying to change the world before I kick the bucket." } \\
\hline G-NMT & \multicolumn{3}{|c|}{ Próbuję zmienić świat, zanim kopnę wiadro. } \\
\hline & G-SMT 2015 & G-NMT 2017 & T-RBMT 2015 \\
\hline $\begin{array}{l}\text { to be in } \\
\text { doldrums }\end{array}$ & aby być w zastoju & być w zagłębieniu & $\begin{array}{l}\text { 1. być w depresji } \\
\text { 2. być w } \\
\text { równikowym pasie } \\
\text { ciszy }\end{array}$ \\
\hline zdanie & \multicolumn{3}{|c|}{ "He's usually in the doldrums in the winter." } \\
\hline G-NMT & \multicolumn{3}{|c|}{ On jest zwykle w zimie. } \\
\hline & G-SMT 2015 & G-NMT 2017 & T-RBMT 2015 \\
\hline $\begin{array}{l}\text { to fly off the } \\
\text { handle }\end{array}$ & do pływania z uchwytu & aby wylać uchwyt & wyjść z siebie \\
\hline zdanie & \multicolumn{3}{|c|}{ "Every time anyone mentions taxes, Mrs. Brown flies off the handle." } \\
\hline G-NMT & \multicolumn{3}{|c|}{$\begin{array}{l}\text { Za każdym razem, gdy ktoś wspomina o podatkach, pani Brown } \\
\text { odrzuca uchwyt. }\end{array}$} \\
\hline & G-SMT 2015 & G-NMT 2017 & T-RBMT 2015 \\
\hline $\begin{array}{l}\text { to show the } \\
\text { white feather }\end{array}$ & $\begin{array}{l}\text { aby pokazać biały } \\
\text { pióro }\end{array}$ & $\begin{array}{l}\text { aby pokazać biały } \\
\text { pióro }\end{array}$ & stchórzyć \\
\hline zdanie & \multicolumn{3}{|c|}{$\begin{array}{l}\text { "The minute Bob put up his fists, Bill showed the white feather and } \\
\text { backed down." }\end{array}$} \\
\hline G-NMT & \multicolumn{3}{|c|}{ W chwili, gdy Bob uniósł pięści, Bill pokazał biały piórko i cofnął się } \\
\hline
\end{tabular}

\section{Wnioski}

Z przytoczonych przykładów dosyć jasno wynika, że translatory automatyczne ciągle nie radzą sobie $\mathrm{z}$ thumaczeniem metafor $\mathrm{w}$ taki sposób, $\mathrm{w}$ jaki byśmy sobie tego życzyli. Zaskakujące jest też to, że gorzej tłumaczą metafory pojęciowe sformułowane w ogólnej i prostej formie, a dużo lepiej konkretne realizacje tych metafor, z tym, że - zachowując sens - tłumaczą je najczęściej dosłownie.

Wydajniejszym i lepszym rozwiązaniem okazuje się przy tym system oparty na sieciach neuronowych, z pewnością w przypadku bardziej szczegółowych realizacji metafor pojęciowych, a należy zauważyć, że i badania nad systemami tego typu, i rynkowy „staż” systemów NMT są dużo krótsze niż systemów RBMT i SMT, wielokrotnie modernizowanych i ulepszanych na przestrzeni już ponad dwudziestu lat. 
Dlatego wydaje się, że przyszłość należy właśnie do systemów NMT, pomimo tego, że również z tłumaczeniem idiomów radzą sobie jeszcze słabo. Nadzieję należy pokładać w tym, że są one w powszechnym użyciu zaledwie od kilku miesięcy, a jak twierdzą ich twórcy - ciągle się uczą. Już dzisiaj, jak pokazuje ostatni przykład, teksty niemetaforyczne tłumaczą popełniając bardzo niewiele błędów.

Stare systemy RBMT, SMT i mieszane są za to ciągle niezastąpione przy thumaczeniu idiomów, chociaż i one czasem się mylą (np. z powodu braku idiomu w bazie słownikowej systemu).

\section{Bibliografia}

Arnold, D. (2003), Why translation is difficult for computers, (w:) H. Somers (red.), Computers and translation: a translator's guide. Amsterdam and Philadelphia, $119-142$.

Bajerowska, A. (2017), Ontologie w systemach informatycznych jako reprezentacje wiedzy, (w:) „Lingwistyka Stosowana” 21: 1/2017, 1-8. (URL http://www.ls.uw.edu.pl/documents/7276721/0/Lingwistyka+Stosowana+21.pdf). [Pobrano 12.06.2017].

Bogucki, Ł. (2009), Ttumaczenie wspomagane komputerowo. Warszawa.

Bondecka-Krzykowska, I., Informacja $w$ informatyce cz. 1. Teoria komunikacji $C$. Shannona. (URL http://www.graniczne.amu.edu.pl/PPGWiki/attach/ InformacjaW1Prezentacja/teoria\%20komunikacji\%20Shannona.pdf). [Pobrano 29.03.2017].

Brown, L. (red.) (1993), The New Shorter Oxford English Dictionary on Historical Principles. New York.

Brown, P.F./ V.J. Della Pietra/ S.A. Della Pietra/ R.L. Mercer (1993), The Mathematics of Statistical Machine Translation: Parameter Estimation. IBM T.J. Watson Research Center, Yorktown Heights, NY 10598. (URL http://www.aclweb.org/anthology/J93-2003). [Pobrano 10.04.2017].

Dunaj, B. (red.) (2001), Popularny stownik języka polskiego. Warszawa.

Gajer, M. (2008), Wielojęzyczne systemy automatycznego przekładu oparte na metodzie wzorów translacyjnych. Kraków.

Gantz, J./ D. Reinsel (2011), Extracting Value from Chaos, Sponsored by EMC Corporation. (URL https://www.emc.com/collateral/analyst-reports/idc-extractin g-value-from-chaos-ar.pdf). [Pobrano 03.04.2017].

Hejwowski, K. (2009), Kognitywno-komunikacyjna teoria przekładu. Warszawa.

Hochreiter, S./ J. Schmidhuber (1997), Long Short-Term Memory, (w:) „Neural Computation" 9 (8), 1735-1780. (URL http://www.mitpressjournals.org/doi/ pdf/10.1162/neco.1997.9.8.1735). [Pobrano 08.04.2017].

Hutchins, J. (2004), Two precursors of machine translation: Artsrouni and Trojanskij, (w:) „International Journal of Translation” 16(1), 11-31. (URL http://www.hutchinsweb.me.uk/IJT-2004.pdf). [Pobrano 12.06.2017].

Kövecses, Z. (2002), Metaphor. A Practical Introduction. Oxford.

Krzeszowski, T.P. (2006), Czy istnieja niemożliwe metafory? - kilka uwag o ograniczeniach metaforyzacji, (w:) G. Habrajska/ J. Ślósarska (red.), 
Kognitywizm w poetyce i stylistyce. Kraków, 37-46.

Lakoff, G./ M. Johnson (1980), Metaphors We Live By. Chicago and London.

Lakoff, G./ M. Johnson (1999), Philosophy in the Flesh: the embodied mind and its challenge to Western thought. New York.

Lakoff, G./ M. Turner (1989), More than Cool Reason. A Field Guide to Poetic Metaphor. Chicago and London.

Le, Q.V./ M. Schuster (2016), A Neural Network for Machine Translation, at Production Scale. (URL https://research.googleblog.com/2016/09/a-neuralnetwork-for-machine.html). [Pobrano 12.03.2017].

Marasek, K./ K. Wołk/ Ł. Brocki/ D. Korzinek (2014), Statystyczne tłumaczenie mowy polskiej. (URL https://www.google.pl/search?q=marasek+t\% $\%$ C5\%82 umaczenie + statystyczne $\&$ ie $=$ utf- $8 \&$ oe $=$ utf- $8 \&$ client $=$ ubuntu\&channel $=$ fs $\&$ gfe $r$ $\mathrm{d}=\mathrm{cr} \& \mathrm{ei}=3 \mathrm{ZJqWbWLDuOv8wfR} 4 J 3 \mathrm{IAw} \& \mathrm{gws}$ rd=ssl). [Pobrano 01.02.2017].

Markiewicz, H. (1984), Wymiary dzieła literackiego. Kraków-Wrocław.

McCulloch, W.S./ W. Pitts (1943), A Logical Calculus of the Ideas Immanent in Nervous Activity, (w:) „Bulletin of Mathematical Biophysics”, Volume 5, 115 133. (URL https://pdfs.semanticscholar.org/5272/8a99829792c3272043842 455f3a110e841b1.pdf). [Pobrano 18.03.2017].

Moses, Statistical Machine Translation System. (URL http://www.statmt.org/mo ses/?n=Moses.Background). [Pobrano 22.03.2017].

Moses, Statistical Machine Translation System. (URL http://www.statmt.org/moses/ index.php?n=Main.HomePage). [Pobrano 22.03.2017].

Moses, Statistical Machine Translation System. (URL http://www.statmt.org/moses/). [Pobrano 22.03.2017].

Nasiadka, M. (2016), Związi frazeologiczne $w$ thumaczeniu ustnym $i$ automatycznym (maszynowym), Gdańsk. Artykuł pokonferencyjny. W druku.

Och, F.J. (2003), Minimum error rate training in statistical machine translation, (w:) „Proceedings of the 41st Annual Meeting on Association for Computational Linguistics" 1. Sapporo, 160-167. (URL http://www.aclweb.org/anthology/P031021). [Pobrano 18.05.2017]

Ping, K. (2011), Machine Translation, (w:) M. Baker/ G. Saldanha (red.), Routledge encyclopedia of translation studies. London and New York, 162-169.

Pisarska, A. (1989), Creativity of Translators. The Translation of Metaphorical Expressions in Non-literary Texts. Poznań.

Pisarska, A./ T. Tomaszkiewicz (1998), Współczesne tendencje przekładoznawcze. Poznań.

Quah, C. K (2006), Translation and technology. Basingstoke.

Rosenblatt, F. (1957), The perceptron, a perceiving and recognizing automaton (Project Para), (w:) Cornell Aeronautical Laboratory report. Buffalo, NY.

Shannon, C.E. (1945), A Mathematical Theory of Cryptography. (URL https:/www.iacr.org/museum/shannon/shannon45.pdf). [Pobrano 05.03.2017].

Shannon, C.E. (1948), A Mathematical Theory of Communication, (w:) ,, Bell System Technical Journal" 27 (3), 379-423. 
Shannon, C.E./W. Weaver (1949), The Mathematical Theory of Communication. Urbana and Chicago.

Szczepańczyk, A. (2015), Tłumaczenie maszynowe wybranych typów idiomów przez translatory Translatica i Google Translate - analiza porównawcza. Praca licencjacka. Uniwersytet Warszawski, Wydział Lingwistyki Stosowanej. Warszawa.

Systran. (URL http://www.systransoft.com/systran/translation-technology/pureneural-machine-translation/). [Pobrano 20.05.2017].

Tsikarishvili, I. (2015), System statystycznego tłumaczenia automatycznego dla języka polskiego i gruzińskiego. Praca magisterska, Uniwersytet im. Adama Mickiewicza w Poznaniu, Wydział Matematyki i Informatyki. Poznań. (URL https://psi.wmi.amu.edu.pl/uploads/Tsikarishvili-mgr-i.pdf). [Pobrano 01.04.2017].

Wu, Y./ M. Schuster/ Z. Chen (i in.) (2016), Google's Neural Machine Translation System: Bridging the Gap between Human and Machine Translation. (URL https://arxiv.org/pdf/1609.08144.pdf). [Pobrano 11.03.2017].

Yushkina, Y. (2017), Even better translations in Chrome, with one tap. (URL https://www.blog.google/products/chrome/even-better-translations-chrome-onetap/). [Pobrano 10.05.2017]. 